\title{
Effects of Impurities on the Percussion and Tensile Properties of Recycled Al-Cu-Si $\left(\mathrm{Cu}_{2} \mathrm{Mg}_{8} \mathrm{Si}_{6} \mathrm{Al} \mathrm{I}_{5}\right)$ Alloys
}

\section{Sujana Rao Nakkanti", Kamprasad Chodagudi, Vijayakumar Chennupati, Mahesh Rayavarapu}

Mechanical Engineering Department, Sai Spurthi Institute of Technology, Sathupally, Khammam, India

Email address:

sujan504@gmail.com (S. R. Nakkanti),kamprasadmech@gmail.com (K. Chodagudi), chennupativk@gmail.com (V. Chennupati), mechnani@gmail.com (M. Rayavarapu)

\section{To cite this article:}

Sujana Rao Nakkanti, Kamprasad Chodagudi, Vijayakumar Chennupati, Mahesh Rayavarapu. Effects of Impurities on the Percussion and Tensile Properties of Recycled Al-Cu-Si $\left(\mathrm{Cu}_{2} \mathrm{Mg}_{8} \mathrm{Si}_{6} \mathrm{Al}_{5}\right)$ Alloys. International Journal of Materials Science and Applications. Vol. 4, No. 6, 2015, pp. 396-402. doi: 10.11648/j.ijmsa.20150406.15

\begin{abstract}
This paper deals with the study of Mechanical properties (Percussion resistance, Ultimate and Yield strength) of cast alloy $\mathrm{Cu}_{2} \mathrm{Mg}_{8} \mathrm{Si}_{6} \mathrm{Al}_{5}$. It has been developed by addition of $\mathrm{Al}-\mathrm{Cu}-\mathrm{Si}$ with $83.334 \% \mathrm{Al}, 16.23 \% \mathrm{Cu}$ and $0.165 \% \mathrm{Si}$. Solidification of Al-Cu-Si alloys has been realized by melting of industrial and machine shop scrap in a pit type resistance furnace with a clay graphite crucible and casting in green sand moulds at maximum temperature of $640^{\circ} \mathrm{C}$. The outcome final castings were then machined according to ASTM-A 370 standards for the percussion, ultimate and yield strength of specimen. The results on the basis of various trails of microstructure and practical approach depicted that $\mathrm{Cu}$ and $\mathrm{Si}$ addition increased the Percussion strength as well as Ultimate and Yield strength for the alloy, while iron addition reduces. However, addition of manganese neutralized the detrimental effects of the iron, which presented in the industrial scrap. The results are given a good agreement with the existing literature on alloys which can be widely used for industrial applications like automobile, aero space, defence etc.
\end{abstract}

Keywords: Al-Cu-Si Alloys, Casting, Percussion Resistance, Microstructure, Ultimate Strength

\section{Introduction}

Aluminium, Copper and Silicon foundry alloys are the most commonly used alloys in the automotive, defence and aerospace industries mainly because of their high strength to weight ratios and excellent cast ability which makes them potential candidates for a number of tribological applications in automobiles and other engineering sectors [1-5]. They also present good wear resistance; high welding characteristics and good surface finish [6]. These alloys are also more strength and high ductility comparative other aluminium casting alloys such as Al-Si alloys [7-8].

The effects of major alloying elements in aluminium are well known and documented. For instance Silicon is known to improve fluidity and reduce solidification shrinkage thus improving cast ability of Silicon based aluminium alloys [9]. It also increase strength until the eutectic level percentage is reached. Copper in the range of between $12-16 \%$ provides optimum ductility whereas greater percentages increase hardness and strength mainly by precipitation hardening. Magnesium is also known to have a similar effect to copper.
Zinc on the other hand makes it possible to achieve the maximum mechanical properties of Aluminium alloys in the as - cast condition [10-15].

Iron as an element is always present in Al-Cu alloys as a carryover of the alloy processing and handling. In concentration of above $0.2 \%$ weight percent Iron had detrimental effects to mechanical properties and manganese is often used to counter its effect. On occasions Iron is deliberately added to $\mathrm{Cu}-\mathrm{Ni}$ groups of alloys to increase their high temperature strength in die-cast alloys, to reduce die shouldering effects. For most of the aluminium alloys however, the detrimental effects out weight their benefits and an effort is made to keeps its level low. Many reputations of load can cause fracture in material even though the maximum stress is far below the ultimate stress. Such a failure is called fatigue failure and may be catastrophic. In high Iron containing alloys beta Phases acts as the preferential site for crack propagation rather than Silicon particles. Copper improves percussion resistance at the expense of ductility and corrosion resistance. Also copper results in the precipitation of $\mathrm{CuAl}_{2}$ particles and depending of cooling rate and 
modifier level, this phase could appear as block $\left(\mathrm{Al}-\mathrm{CuAl}{ }_{2}\right)$ fine eutectic colonies in the microstructure [16-18]. S Kumar Jha. et al [21]. Discussed about the ultimate strength of the AA 6060 and AA 6160 for the microstructure of the facture surface after tensile strength has been examined using inverted micro scope.

Percussion and ultimate strength are recommended in aviation and automobile parts that experience shock loads. Brittle failures result from stress raisers that originate from notches, poor surface finish are micro structure features (such as porosity, inter metallic, oxides and grain size) [19]. The percussion test is use full in determining the ability of a material to absorb energy during deformation. This study focus on the effect of Iron, Titanium and Manganese as additives on fatigue and percussion properties of recycled aluminium alloy [20].

\section{The Experimental Process}

The molten metal used in this study was obtained from scrap aluminum-83.334\%, Copper-16.23\% and Silicon$0.165 \%$. These were melted in clay graphite crucible in a pit type resistance furnace under a cover flux to prevent oxidation and hydrogen pickup and heated to a temperature of $640^{\circ} \mathrm{C}$ and $\mathrm{Mn}$-Ti master alloy added to achieve a $0.011 \mathrm{wt}$ percent and $0.002 \mathrm{wt}$ percent manganese and titanium concentration respectively. The melt was stirred for $30 \mathrm{~s}$ with zirconium coated iron rod after addition of grain refiner. Melts were held for $5 \mathrm{~min}$ and poured into a green sand mould surrounded by fire clay brick. The chemical compositions of the cast alloy are given in table 1 .

After solidification the moulds were broken and the castings machined according to ASTM-A 370 standards for the specimen for percussion, Ultimate and the yield strength testing. The percussion test was carried out using the charpy percussion testing machine with the following characteristics; hammer-20.932 kg, arm length- $0.825 \mathrm{~m}$, Swing angle-126 ${ }^{\circ}$ and lift angle- $140^{\circ}$ Figure 1(a) indicates Percussion Strength tested specimen. The tensile test was carried out by Universal Testing Machine (UTM) of 2 ton capacity as per the ASTMA 370 standards. The specimen is used to calibrate as shown in figure 1(b). The microstructure specimens of about above $30 \mathrm{~mm}$ cube were wet ground, polished and etched. Using the Inverted microscope, photo micrographs were taken at different magnifications.

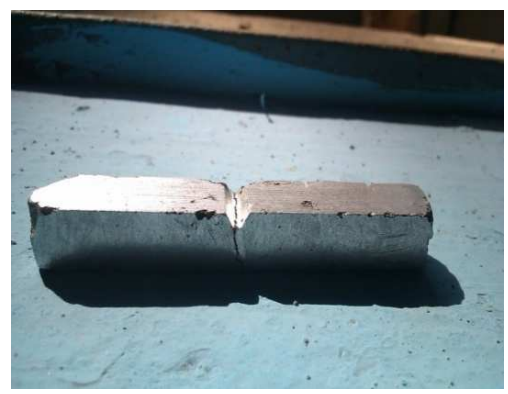

Figure 1(a). Percussion strength tested specimen.

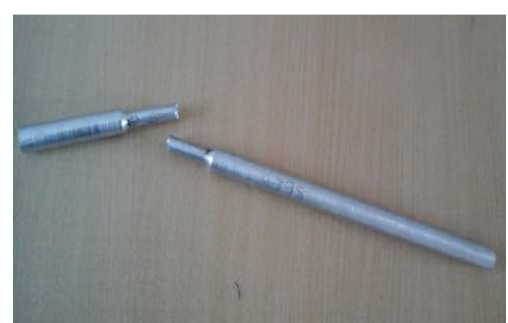

Figure 1(b). Tensile tested specimen.

\section{Results}

\subsection{Chemical Analysis}

The results obtained from the chemical composition analysis are presented in the table 1 .

Table 1. Chemical composition of alloys.

\begin{tabular}{ll}
\hline Alloy element & \% of composition \\
\hline $\mathrm{Si}$ & 0.165 \\
$\mathrm{Fe}$ & 0.016 \\
$\mathrm{Cu}$ & 16.23 \\
$\mathrm{Mn}$ & 0.011 \\
$\mathrm{Mg}$ & 0.108 \\
$\mathrm{Zn}$ & 0.001 \\
$\mathrm{Cr}$ & 0.132 \\
$\mathrm{Ti}$ & 0.002 \\
$\mathrm{Al}$ & 83.334 \\
\hline
\end{tabular}

\subsection{Results of the Percussion Test}

The percussion test energy value was calculated from the absorbed energy Equation 1.

$$
\mathrm{E}=\mathrm{P} * \mathrm{D} *(\operatorname{Cos} \beta-\operatorname{Cos} \alpha)
$$

where;

$\alpha-$ lift angle.

$\beta$ - Swing angle.

$\mathrm{P}$ - Weight of the pendulum system D - Distance from the centre of gravity.

Table 2 and Figure 2 gives a summary of the charpy test for percussion resistance $\left(\mathrm{J} / \mathrm{Cm}^{2}\right)$.

Percussion resistance value is calculated from the following Equation 2.

Percussion Resistance $=\frac{\text { Energy absorbed by specimen }(\mathrm{J})}{\text { Cross sectional area of specimen }\left(\mathrm{Cm}^{2}\right)}(2)$

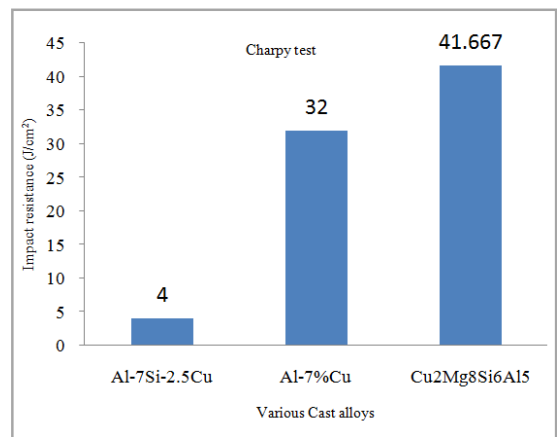

Figure 2. Percussion strength variation for different cast alloys. 
Table 2. Percussion Resistance Value.

\begin{tabular}{lllllll}
\hline S. No & Alloy & Breadth $(\mathbf{C m})$ & Depth $(\mathbf{C m})$ & Cross sectional Area $\left(\mathbf{C m}^{2}\right)$ & Energy absorbed $(\mathbf{J})$ & $\begin{array}{l}\text { Percussion resistance } \\
\left(\mathbf{J} / \mathbf{C m}^{2}\right)\end{array}$ \\
\hline 1 & $\mathrm{Cu}_{2} \mathrm{Mg}_{8} \mathrm{Si}_{6} \mathrm{Al}_{5}$ & 0.9 & 0.8 & 0.72 & 30 & 41.66 \\
\hline
\end{tabular}

\subsection{Results of the Tensile Test}

The tensile test carried out for the ultimate and yield strength by Equation 3 and 4.

$$
\begin{gathered}
\text { Ultimate Strength }=\frac{\text { Ultimate Load }\left(\mathrm{W}_{\mathrm{u}}\right)}{\text { Cross sectional Area of the Specimen }\left(\mathrm{A}_{\mathrm{u}}\right)} \\
\text { Yield Strength }=\frac{\text { Yield Load }\left(\mathrm{W}_{\mathrm{y}}\right)}{\text { Cross sectional Area of the Specimen }\left(\mathrm{A}_{\mathrm{y}}\right)}
\end{gathered}
$$

By using of these equations and practical approach depicts that good increment has given with existing properties.

\subsection{Microstructures}

The Microstructure of Al-Cu-Si alloys can play an important role both in its mechanical and corrosion behaviour. It was found that a better corrosion resistance tendency is achieved for pure metals with coarser macrostructures and that the type of macrostructural morphology (columnar or equiaxed grains) can also affect the corrosion resistance. Figure 3 gives a summary of the microstructures at different magnifications.

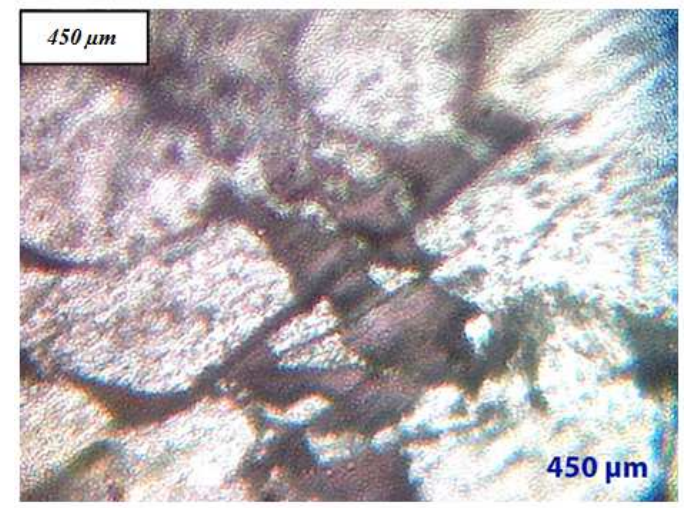

a) Microstructure for Specimen A at $450 \mathrm{X}$ magnification.

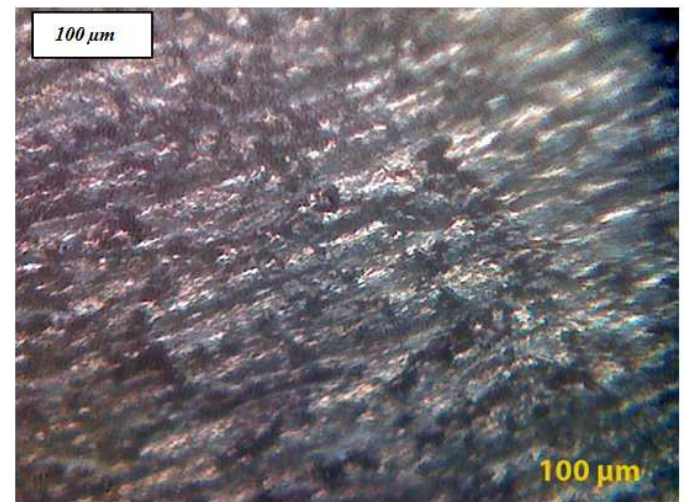

b) Microstructure for Specimen A at $100 \mathrm{X}$ magnification.

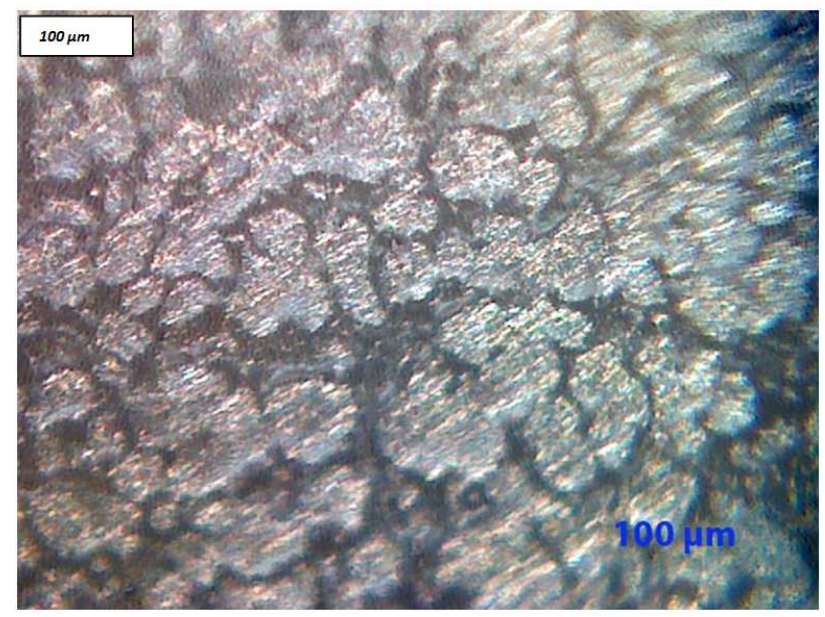

c) Microstructure for Specimen B at 100 X magnification.

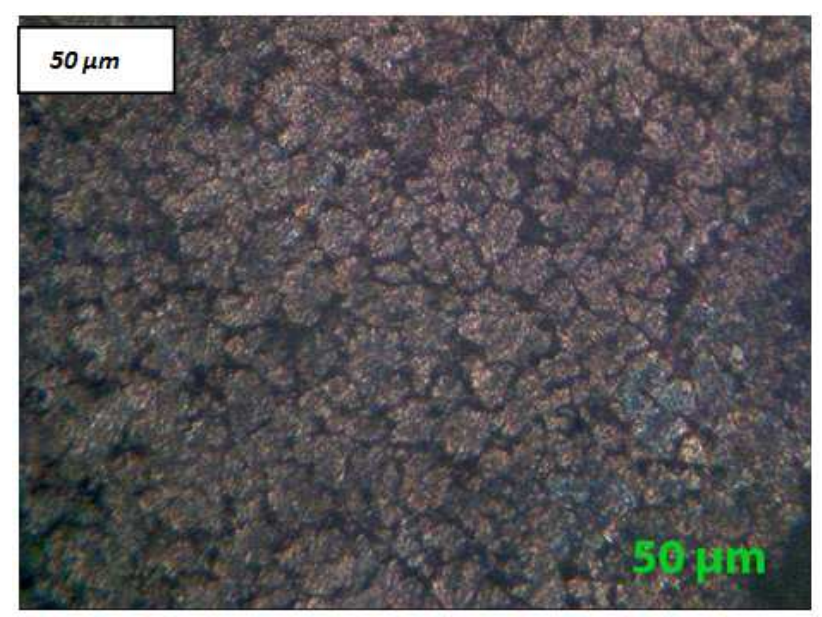

d) Microstructure for Specimen B at $50 \mathrm{X}$ magnification.

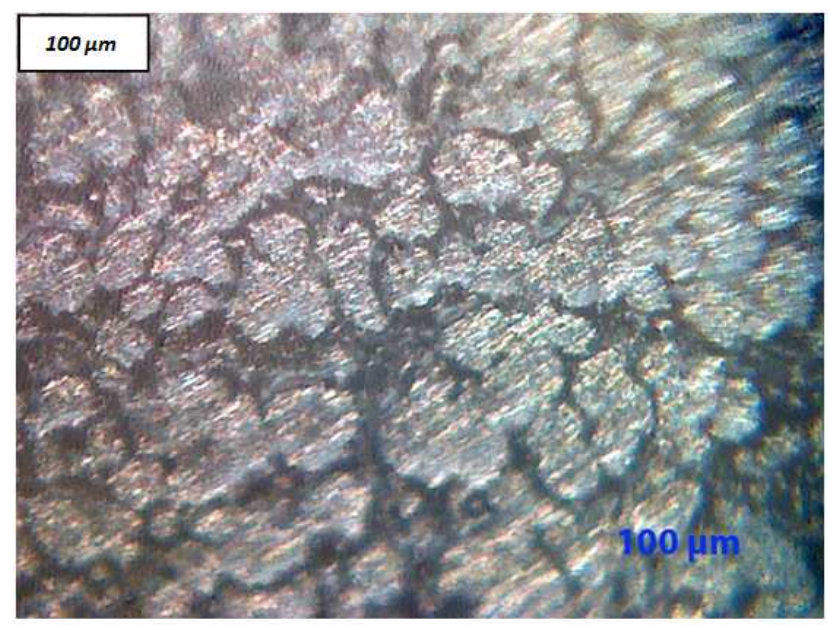

e) Microstructure for Specimen c at $100 \mathrm{X}$ magnification. 


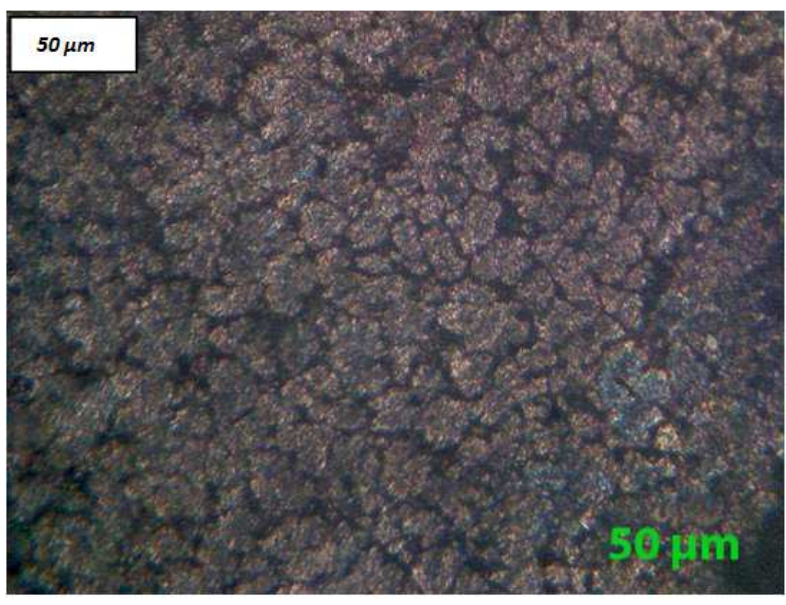

f) Microstructure for Specimen c at $50 \mathrm{X}$ magnification.

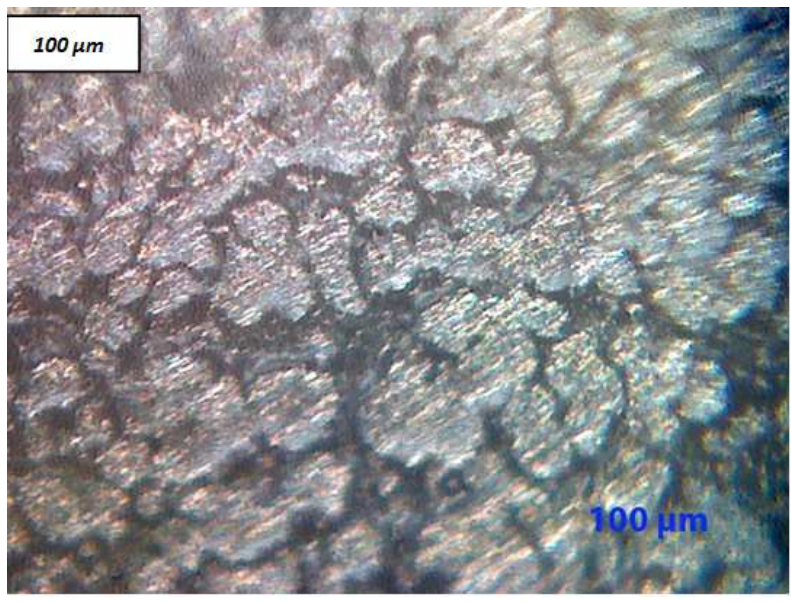

g) Microstructure for Specimen d at $100 \mathrm{X}$ magnification.

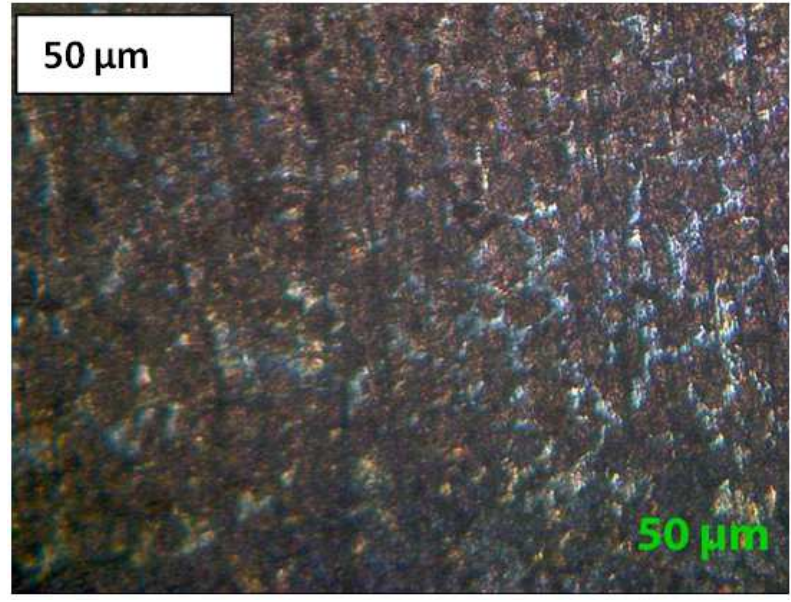

h) Microstructure for Specimen d at $50 \mathrm{X}$ magnification.

Figure 3. (a-h) Microstructures for Cu2Mg8Si6Al5 Cast alloy at different magnifications.

\section{Discussion}

\subsection{The Effect of Impurities on Aluminium Alloy}

To determine the effect of additives on percussion properties of Aluminium alloys, it has necessary that comparisons between the base aluminium alloy and the test specimen are made. $\mathrm{Mg}$ : $\mathrm{Si}$ ratio is less than 1 . Then $\mathrm{Cu}_{2} \mathrm{Mg}_{8} \mathrm{Si}_{6} \mathrm{Al}_{5}$ cast alloy is formed. Percussion strength of $\mathrm{Cu}_{2} \mathrm{Mg}_{8} \mathrm{Si}_{6} \mathrm{Al}_{5}$ cast alloy mainly depends on the shape, size and weight percentage of composition and distribution of the grains in microstructure as shown in Figure $3(a-h)$. The effect of silicon increases the strength in cast alloys, mainly by increasing the cast ability and thus the soundness of the castings. In the $10-16 \% \mathrm{Cu}$ alloys there is little difference in structure between the as cast and heat treated alloys. Copper is added to alloys to increase their Percussion and Ultimate strength as shown in Figure 4(a-e), hardness, fatigue and creep resistances and machinability. Copper is high solubility in $\mathrm{Al}, \mathrm{Al}-\mathrm{Cu}$ matrix i. e., tougher than a pure Aluminium matrix and high corrosion resistance.

Table 3. Experimental work on various trials on various specimens.

\begin{tabular}{lllllll}
\hline \multirow{2}{*}{$\begin{array}{l}\text { Specimen } \\
\text { No }\end{array}$} & \multicolumn{7}{l}{ Percussion Resistance value } & $\left(\mathbf{J} / \mathbf{C m}^{2}\right)$ & & \begin{tabular}{l} 
Mean \\
value \\
\cline { 2 - 6 }
\end{tabular} & Trial 1 & Trial 2 & Trial 3 & Trial 4 & Trial 5 & ( $\left.\mathbf{C m}^{2}\right)$ \\
\hline A & 42 & 44.49 & 45.49 & 41 & 44.47 & 43.49 \\
B & 40.47 & 36 & 38.98 & 35.4 & 41.5 & 38.47 \\
C & 38.69 & 47.09 & 46 & 42 & 40.67 & 42.89 \\
D & 39.5 & 44.08 & 46.05 & 40 & 38.87 & 41.79 \\
Mean Value $\left(\mathrm{J} / \mathrm{Cm}^{2}\right)$ & & & & & 41.66 \\
\hline
\end{tabular}

Table 4. Ultimate and Yield strength Values for Various Specimens.

\begin{tabular}{llllll}
\hline S. No & Specimen & $\begin{array}{l}\text { Ultimate } \\
\text { strength } \\
\text { (Mpa) }\end{array}$ & $\begin{array}{l}\text { Yield } \\
\text { Strength } \\
\text { (Mpa) }\end{array}$ & $\begin{array}{l}\text { \% of } \\
\text { Elongation }\end{array}$ & $\begin{array}{l}\text { \% of } \\
\text { Reduction } \\
\text { Area }\end{array}$ \\
\hline 1 & A & 234.86 & 152.78 & 5.7 & 48.87 \\
2 & B & 241.013 & 176.81 & 7.1 & 56.6 \\
3 & C & 216.45 & 128.2 & 4.76 & 38.2 \\
4 & D & 236.69 & 159.8 & 6.25 & 51 \\
5 & E & 246.16 & 176.62 & 6.19 & 53.5 \\
\hline
\end{tabular}

\subsection{The Microstructures of $\mathrm{Cu}_{2} \mathrm{Mg}_{8} \mathrm{Si}_{6} \mathrm{Al}_{5}$ Cast Alloy Treated by Grain Refiner and Modifier}

The microstructures of the $\mathrm{Cu}_{2} \mathrm{Mg}_{8} \mathrm{Si}_{6} \mathrm{Al}_{5}$ cast alloys before and after grain refinement, modification and combined addition of both refiner and modifier are shown in Fig. 3(a-h). It is observed that grain refinement, modification and combined addition of both refiner and modifier have profound influence on microstructures of the $\mathrm{Cu}_{2} \mathrm{Mg}_{8} \mathrm{Si}_{6} \mathrm{Al}_{5}$ cast alloy. Fig. 3(a-h) shows the microstructures of treated ( $1 \mathrm{wt} \%$ Al-0.011Mn- $0.132 \mathrm{Cr}$ grain refiner) alloys consisting of fine equated $\alpha-\mathrm{Al}$ grains (soft phase), uniformly distributed fine eutectic mixture and fine $\mathrm{CuAl}_{2}$ particles in inter dendrite region. The present experimental work confirms that addition of grain refiner $(1 \mathrm{wt} \% \mathrm{Al}-0.011 \mathrm{Mn}-0.132 \mathrm{Cr})$ to $\mathrm{Cu}_{2} \mathrm{Mg}_{8} \mathrm{Si}_{6} \mathrm{Al}_{5}$ alloy significantly refines the coarse columnar primary $\alpha-$ $\mathrm{Al}$ grains to fine equated $\alpha-\mathrm{Al}$ grains due to the presence of $\mathrm{AlCr}_{2} / \mathrm{TiCr}_{2}$ particles present in the master alloy which 
are nucleating agents during the solidification of $\alpha$-Al dendrites (soft phase), while the eutectic silicon particles appear to be unaffected as expected. Also the addition of modifier $(0.002 \mathrm{wt} \% \mathrm{Ti})$ to $\mathrm{Cu}_{2} \mathrm{Mg}_{8} \mathrm{Si}_{6} \mathrm{Al}_{5}$ alloy changes the plate-like eutectic silicon to uniformly distributed fine particles (eutectic) and fine $\mathrm{CuAl}_{2}$ particles in the interdendritic region. The results also suggest that the addition of Al-0.011Mn-0.132 Cr master alloy along with Ti modifier to $\mathrm{Cu}_{2} \mathrm{Mg}_{8} \mathrm{Si}_{6} \mathrm{Al}_{5}$ cast alloy shows more uniformly distributed $\alpha-\mathrm{Al}$ dendrites, fine silicon and $\mathrm{CuAl}_{2}$ particles in the inter dendrite region compared to the individual addition of grain refiner or modifier. It is important to note that the alloys have been cast in a graphite mould surrounded by fire clay brick (slow cooling). Thus, further improvement in the percussion toughness, ultimate strength and the yield strength can be expected for fast cooled castings, as this can lead to further refinement of the micro structures. Finally the fast cooled casting is the good.

\subsection{Influence of the Micro Structural Changes on Percussion and Ultimate Strengths}

Percussion and Ultimate strength of the $\mathrm{Cu}_{2} \mathrm{Mg}_{8} \mathrm{Si}_{6} \mathrm{Al}_{5}$ cast alloy mainly depends on the shape, size and size distribution of the $\alpha$-Al grains (soft phase), eutectic silicon morphology and $\mathrm{CuAl}_{2}$ blocks in the inter dendrite region. Table $3 \& 4$ gives the Percussion resistance and ultimate strength values of the various samples during the test. As illustrated in Table 3\&4, the Percussion resistance and Ultimate strength values of the $\mathrm{Cu}_{2} \mathrm{Mg}_{8} \mathrm{Si}_{6} \mathrm{Al}_{5}$ cast alloy increases with the addition of grain refiner ( $1 \mathrm{wt} \% \mathrm{Al}-$ $0.011 \mathrm{Mn}-0.132 \mathrm{Cr}$ ) and modifier (Ti).

As shown in Fig. 2(a-h), the microstructure of $\mathrm{Cu}_{2} \mathrm{Mg}_{8} \mathrm{Si}_{6} \mathrm{Al}_{5}$ alloy treated with the combined addition of both grain refiner ( $1 \mathrm{wt} \% \mathrm{Al}-0.011 \mathrm{Mn}-0.132 \mathrm{Cr})$ and modifier (Ti) along with copper consists of more uniformly distributed $\alpha-\mathrm{Al}$ dendrites (soft phase), fine broken grains of silicon and inter metallic fine $\mathrm{CuAl}_{2}$ phase formed along the inter dendrite region, which further improves the percussion resistance and ultimate strength. The percussion resistance increases markedly with a combined addition of grain refiner and modifier along with copper, reaching the value of over $40 \pm 1.66 \mathrm{~J} / \mathrm{cm}^{2}$. The Ultimate strength increased and reached an optimum point at $246.16 \mathrm{Mpa}$ and various for small diameter specimens under suitable load conditions. The Yield strength is also verified by UTM test for various diameters for the suitable load conditions as shown figure 4(e). This value of percussion resistance is ten times that of the untreated Al-12Si alloy. The effect of other additions like only grain refiner ( $1 \mathrm{wt} \%$ Al-0.011Mn- 0.132 $\mathrm{Cr}$ ) and only modifier (Ti) on percussion resistance of eutectic alloys is also shown in Table 3 , these have limited effect only Figure 4. (a-d) shows the percussion resistance values for specimens (a-d) at various trials respectively. The mean percussion resistance value is taken among them.

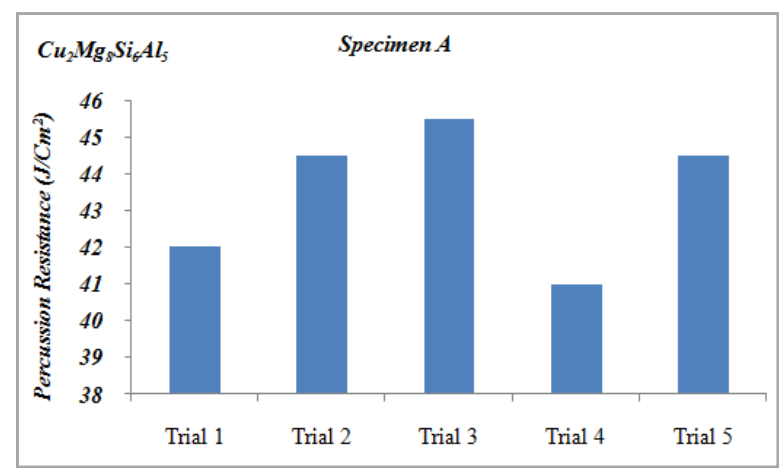

a) Percussion resistance values for specimen $\mathrm{A}$ at various trials.

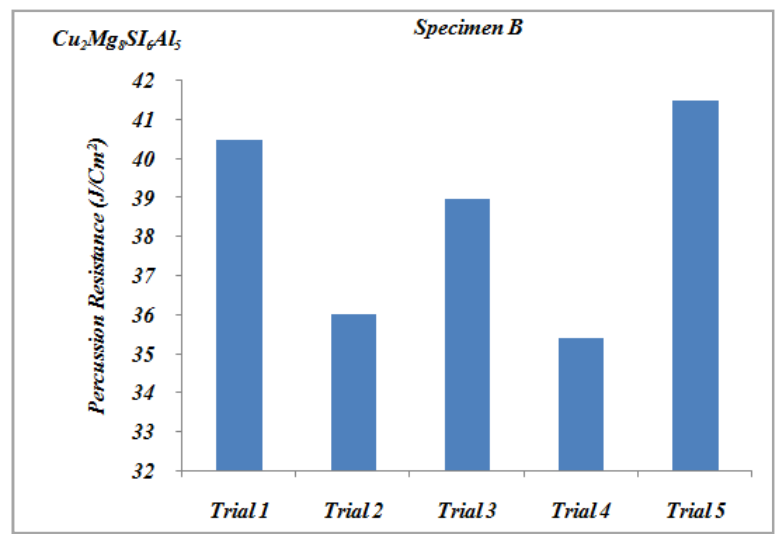

b) Percussion resistance values for specimen B at various trials.

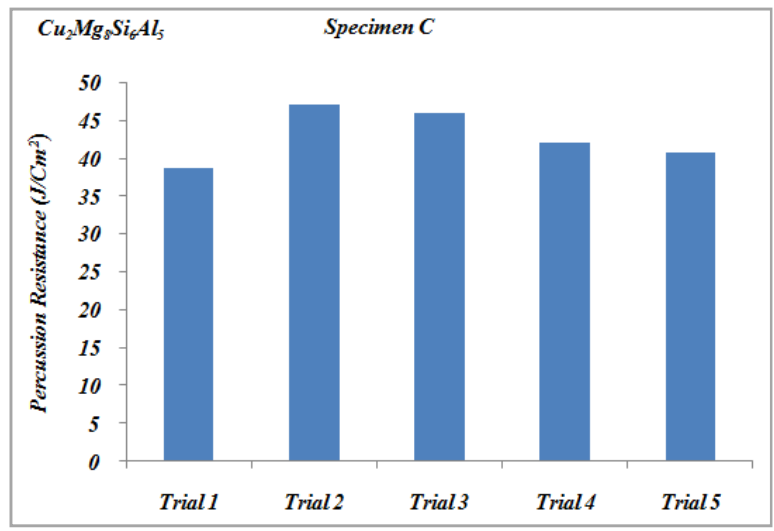

c) Percussion resistance values for specimen $\mathrm{C}$ at various trials.

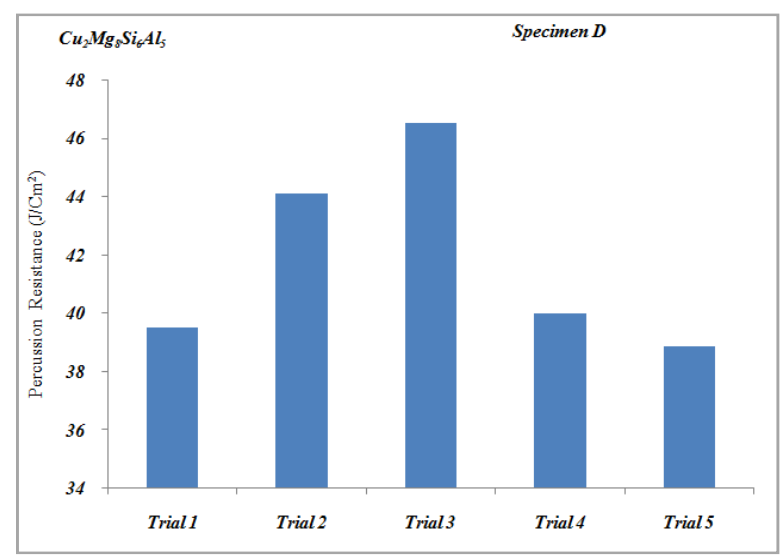

d) Percussion resistance values for specimen at various trials. 


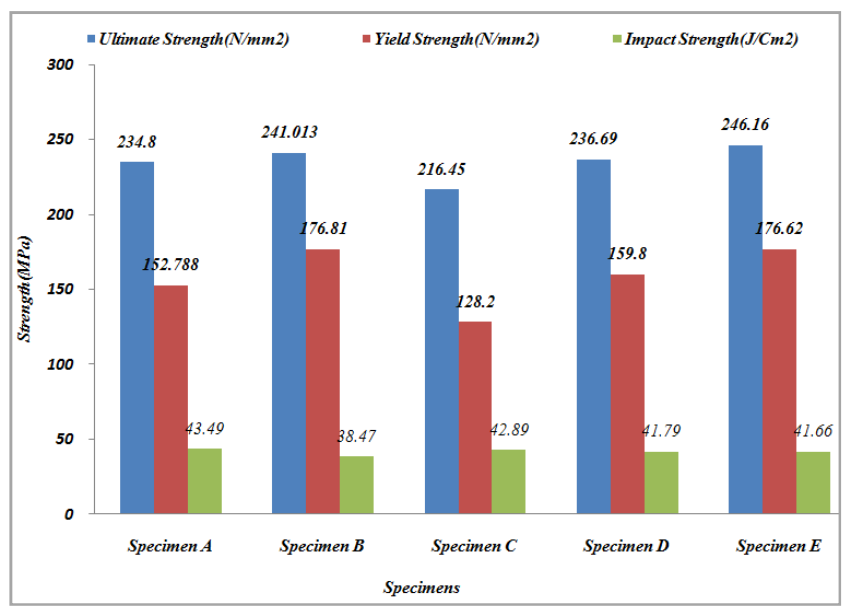

e) Ultimate, Yield Strength and Impact Resistance values for various Specimens

Figure 4. (a-e). Percussion resistance, Ultimate and Yield strength values for various specimens.

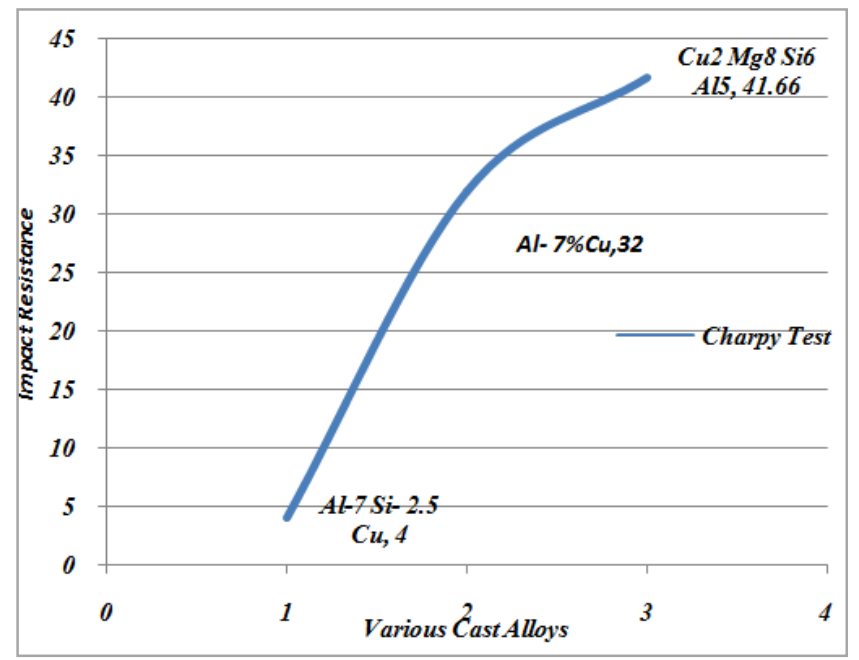

Figure 5. Percussion resistance variation for different Cast Alloys.

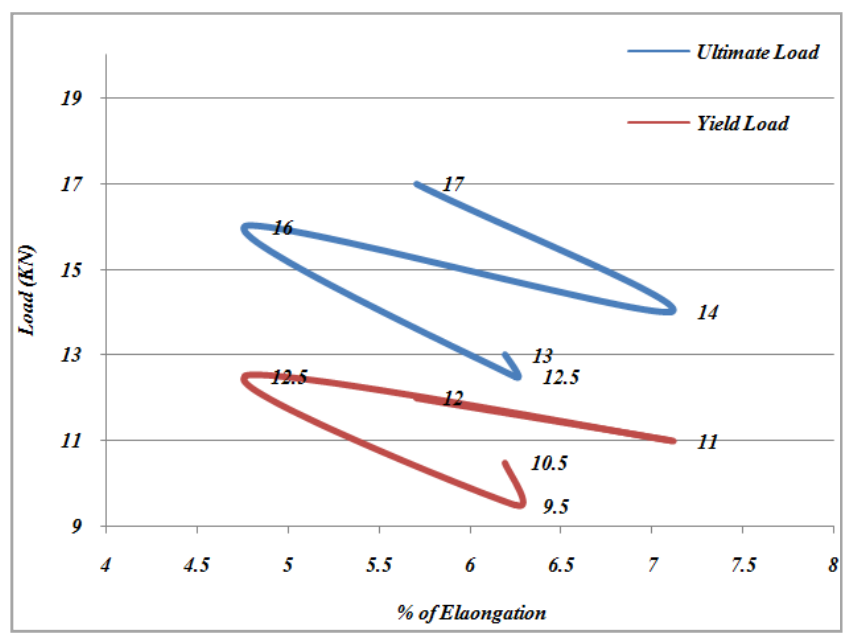

Figure 6. Percentage of Elongation for Different Diameter and Loaded Specimens.

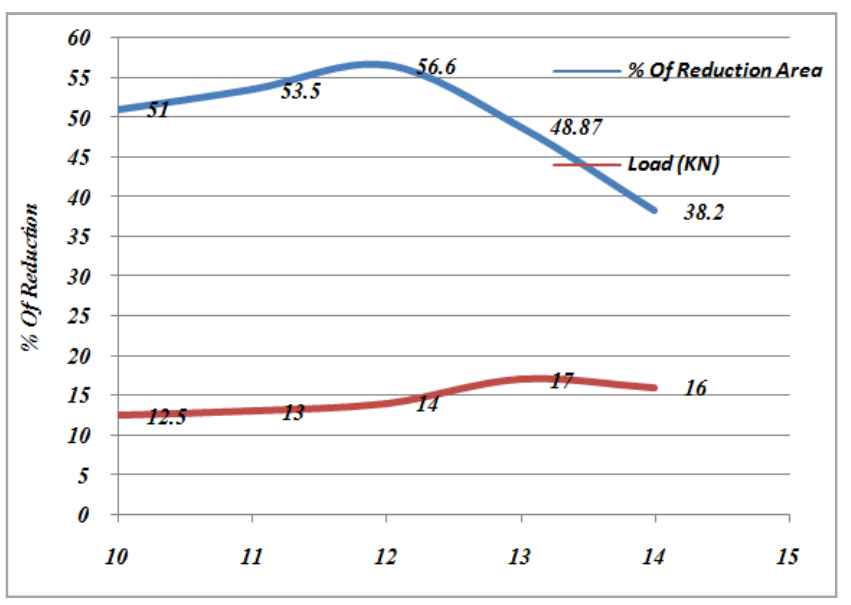

Figure 7. Change of area in percentage for various loads and diameter.

\section{Conclusions}

The effect of Impurities ( $\mathrm{Cu}, \mathrm{Si}, \mathrm{Cr}$ and $\mathrm{Ti})$ and microstructure changes on the Percussion resistance, Ultimate and Yield strength of the $\mathrm{Cu}_{2} \mathrm{Mg}_{8} \mathrm{Si}_{6} \mathrm{Al}_{5}$ Cast alloy was investigated and the following conclusions could be drawn as shown in Figure 4-7.

1. It was observed that Percussion strength of $\mathrm{Cu}_{2} \mathrm{Mg}_{8} \mathrm{Si}_{6} \mathrm{Al}_{5}$ Cast alloy mainly depends on the shape, type, size and size distribution of $\alpha-\mathrm{Al}$ grains, silicon particles and $\mathrm{CuAl}_{2}$ phases in the matrix.

2. The measurements performed confirmed that the percussion Ultimate and Yield strength properties are mainly influenced by the sizes of the soft phase and eutectic constituents in the alloys.

3. The increase in percussion resistance ultimate and yield strength consists of two parts: the breakage of the large aluminum dendrites into more uniformly distributed $\alpha$ Al dendrites by refinement and the plate-like eutectic silicon to fine broken particles of silicon and massive blocks of $\mathrm{CuAl}_{2}$ to fine micro constituents of $\mathrm{CuAl}_{2}$ by modification.

4. The combined addition of grain refiner and modifier (1 wt $\%$ Al-0.011Mn-0.016 $\mathrm{Cr}$ ) to $\mathrm{Cu}_{2} \mathrm{Mg}_{8} \mathrm{Si}_{6} \mathrm{Al}_{5}$ alloy shows remarkably improved percussion resistance $\left(41.66 \mathrm{~J} / \mathrm{cm}^{2}\right)$ when compared to $\mathrm{Al}-12 \mathrm{Si}-3 \mathrm{Cu}$ alloy $\left(8.73 \pm 0.1 \mathrm{~J} / \mathrm{cm}^{2}\right)$ and untreated $\mathrm{Al}-12 \mathrm{Si}$ alloy $(1.63 \pm$ $\left.0.5 \mathrm{~J} / \mathrm{cm}^{2}\right)$. Ultimate $(246.16 \mathrm{MPa})$ and Yield strength $(176.81 \mathrm{MPa})$ are also remarkably changed with the existing [21] AA6061 grade aluminum alloy (194MPa).

\section{Acknowledgement}

The authors acknowledge Sai Spurthi Institute of Technology for sponsoring this work.

\section{References}

[1] Mondlofo LF. Aluminium: structures and properties. UK: Butterworth; 1979. p. 756-75. 
[2] ASM Handbook, casting. Metal Park, OH: ASM International; 1989. p. 785-91.

[3] Kori SA, Murthy BS, Chakraborthy M. Mater Sci Eng 2000; A283: 94-104.

[4] ASTM Standard E647. Standard test method for measurement of fatigue crack growth rates. Annual book of ASTM Standards, vol. 03.01, 2000.

[5] Lasa L, Ibabe JMR. Scr Mater 2002; 46: 477.

[6] J.G. Kaufman and E. L. Rooy, "Aluminium alloy Castings, Properties, processes and Applications," American Foundry Society, 2004.

[7] Basavakumar K G, Mukunda P G and Chakraborty M 2006 Trans. Indian Inst. Met. 59400.

[8] Basavakumar K G, Mukunda P G and Chakraborty M "Effect of melt treatment on Al-7Si and Al-7Si-2.5 Cu cast Alloys". Indian Academy of Sciences. Vol. 30, No. 5, pp. 439-445 October 2007.

[9] Aluminium - Copper alloys: "Key to metal articles" Handbook, 2013.

[10] Green NR, Campbell J. AFS Trans 1994; 102: 341-7.

[11] Skallerud B. Eng Fract Mech 1993; 44 (6): 857-74.
[12] Iwahashi Y, Wang J-T, Horita Z, Nemoto M, Langdon TG. Scr Mater 1996; 35: 143.

[13] Nishida Y, Arima H, Kim J-C, Ando T. Scr Mater 2001; 45: 261.

[14] Nishida Y, Ando T, Nagase M, Lim S-W, Shigematsu I, Watazu A. Scr Mater 2002; 46: 211.

[15] Akamatsu H, Fujinami T, Horita Z, Langdon TG. Scr Mater 2001; 44: 759.

[16] Watanabe H, Mukai T, Ishikawa K, Higashi K. Scr Mater 2002; 46: 851 .

[17] Mabuchi M, Iwasaki H, Yanase K, Higashi K. Scr Mater 1997; 36: 681 .

[18] Neishi K, Horita Z, Langdon TG. Scr Mater 2001; 45: 965.

[19] A. M. Samuel, "parameters controlling the performance of A319-type alloys: Impact properties and Fractography," Vol. A367, pp. 111-122, 2004.

[20] ASTM Standard A370 2000 Standard test method for measurement of Impact Strength for Specimens.

[21] S Kumar Jha et al. "Experimental analysis of mechanical properties on AA 6060 and AA 6061 Aluminum alloys" IJERA, Vol. 5, Issue 4, pp 47-53, April 2015. 